\title{
Variations in coastal fish species composition captured by traps in Romsdalsfjord, Western Norway
}

\author{
Pablo Arechavala-Lopez • Marius Berg • Ingebrigt Uglem • \\ Pål-Arne Bjørn • Bengt Finstad
}

Received: 24 November 2015/Accepted: 17 February 2016/Published online: 3 March 2016

(c) The Author(s) 2016. This article is published with open access at Springerlink.com

\begin{abstract}
Fish traps are widely used in Norwegian fjords, especially those designed for monitoring salmonid populations in the marine environment, although many other marine fish species are also captured. The composition and spatio-temporal variations of fish species captured by fish traps were monitored in five different coastal locations throughout the Romsdalsfjord region, Western Norway, from May to August during the three consecutive years (2011-2013). Twenty-three fish species were captured by traps in coastal waters, both resident and migratory fishes. The most common fish and with greater catchability were saithe (Pollachis virens) and sea trout (Salmo trutta), followed by cod (Gadus morhua), pollack (P. pollachius), herring (Clupea harengus) and mackerels (Trachurus trachurus and Scomber scombrus). However, the captured assemblage presented great spatial and seasonal variations, in terms of mean daily catch, probably associated with hydrographical conditions and migrational patterns. Information obtained in this study will help us to better understand the compositions and dynamic of coastal fish populations inhabiting Norwegian coastal waters. In addition, traps are highly recommended as a management tool for fish research (e.g. fish-tagging experiments, mark and recapture) and conservation purposes (coastal use and fisheries studies).
\end{abstract}

Keywords Catches $\cdot$ Fish assemblage $\cdot$ Seasonality $\cdot$ Coastal management $\cdot$ Temperature $\cdot$ Salinity

\section{Introduction}

Fish traps are stationary fixed structures to which fish or shellfish are led into an enclosure and trapped (He and Inoue 2010). Traps are commonly used in marine and freshwater environments for recreational and professional fishing, presenting diverse and appropriate designs and handling protocols according to the target species (Gabriel et al. 2005; He and Inoue 2010). For instance, traps are commonly used in Norwegian waters and specifically designed for capturing wild salmonids (e.g. Halttunen et al. 2009; Liu et al. 2011; Skilbrei and Holm 2011), escaped salmonids from fish farms (e.g. Skilbrei and Jørgensen 2010; Chittenden et al. 2011; Liu et al. 2011; Solem et al. 2013), but also to monitor parasitic infestations of salmon lice (Lepeophtheirus

\footnotetext{
P. Arechavala-Lopez $(\bowtie)$

Department of Marine Science and Applied Biology, University of Alicante, P.O. Box 99, 03080 Alicante, Spain

e-mail: pablo.arechavala@ua.es

P. Arechavala-Lopez $\cdot$ M. Berg $\cdot$ I. Uglem · B. Finstad

Norwegian Institute of Nature Research, Trondheim, Norway

P.-A. Bjørn

Institute of Marine Research, Bergen, Norway
} 
salmonis) (e.g. Barlaup et al. 2013; Skaala et al. 2014; Arechavala-Lopez et al. 2016). However, many other fish species are regularly caught by traps, but they are scarcely reported in aforementioned studies. Traps hardly cause damages or mortalities among trapped fish so they are more recommended than other fishing methods (i.e. netting, angling) for fish research and conservation purposes (Barlaup et al. 2013). Information about the presence of fish species captured by this kind of traps should help to better understand the dynamics of coastal fish populations along Norwegian coast, which are important nursery areas for several species (Olsen et al. 2010). Diversity and distribution of Norwegian coastal fish species are influenced by tidal effects, complexity of habitat and competition among species at a local scale, and coastal currents, anthropogenic effects and climate changes at a larger scale (e.g. Salvanes and Nordeide 1993; Lekve et al. 1999; Olsen et al. 2010). However, studies about ecological processes and spatio-temporal fluctuations of coastal fish communities throughout Norway are scarce. Therefore, the aim of this study was to assess the presence, composition and spatio-temporal variations of fish species captured with traps in a Norwegian fjord system, providing interesting and useful information for understanding the variability and dynamic coastal fish assemblages.

\section{Materials and methods}

The present study was carried out in the Romsdalsfjord region, Western Norway $\left(62.6523^{\circ} \mathrm{N}, 7.2615^{\circ} \mathrm{E}\right)$. Five sampling locations with similar characteristics (sheltered and coastal shallow waters on rocky/sandy bottom) were selected throughout the fjord system, which are named (from the outermost to the innermost): Vatnefjorden, Frænfjorden, Bolsøya, Måndalen and Eresfjord (Fig. 1). In each location, one fish trap was set during 2-week sampling periods from May to August for three consecutive years (2011-2013). These traps are specifically designed to capture sea trout, and might be generally described as an anchored netting structure which consists in two wings and a lead net that form the entrance to an open cube. This cube leads the fish into a tunnel with consecutive funnels and residence chambers, where the fish are trapped (Barlaup et al. 2013). These particular fish traps consisted of a lead net $(50 \mathrm{~m}$ long $\times 5 \mathrm{~m}$ high) and two wings $(10 \mathrm{~m} \mathrm{long} \times 5 \mathrm{~m}$

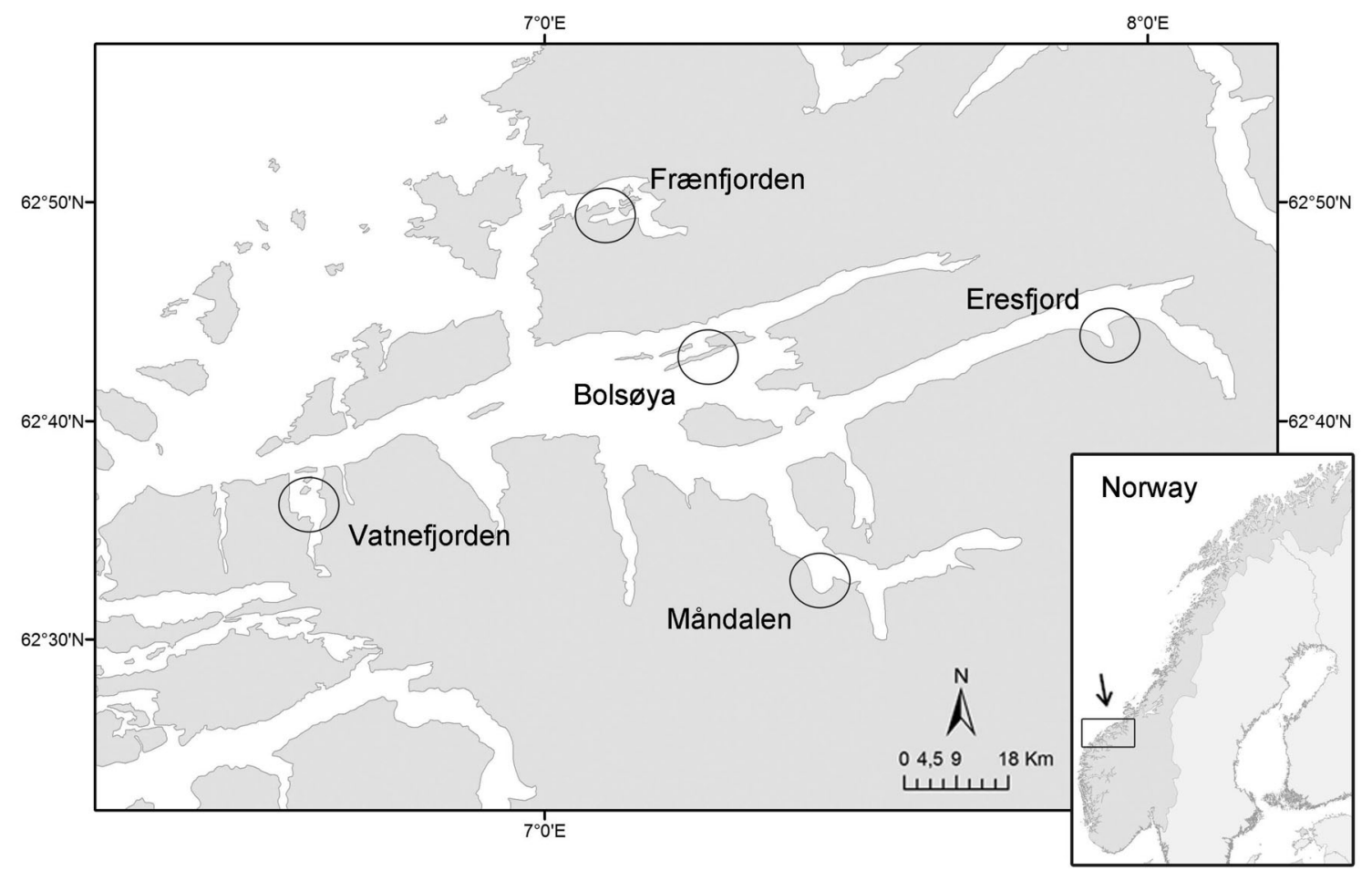

Fig. 1 Map of Romsdalsfjord (Norway) showing the sampling locations where traps (circles) were deployed during the study period 
high), leading to an open cube ( $5 \mathrm{~m}$ long $\times 5 \mathrm{~m}$ high $\times 5 \mathrm{~m}$ wide) and into consecutive chambers (approx. $2.5 \mathrm{~m}$ long $\times 1.2 \mathrm{~m}$ diameter) where the fish are trapped (for further details see Barlaup et al. 2013). Traps were put out from a small boat and attached to the shoreline, covering a depth range from 0 to $5 \mathrm{~m}$ depth. Moreover, anti-seal devices were inserted into the neck of the traps during the 2012-2013 sampling periods. The devices consist of a crossed-wire square grid fixed in the funnel of the trap, which gave four square entrances of $22.5 \mathrm{~cm}$ each. The grid, similar to that one described by Lehtonen and Suuronen (2004), prevents the entrance of seals and lets in a wide size range of fishes. Trapped fish are usually alive and unharmed, allowing selective fish harvesting and live releasing without modification on fish migration behaviour, if handled properly (Siira et al. 2006; He and Inoue 2010; Barlaup et al. 2013).

Presence of captured fish species was daily recorded. Unharmed individuals were released far from the fishing spot to avoid quick recaptures. Those fish species with low presence and abundance within catches were grouped together according to similarities on taxonomic levels (i.e. gadids, mackerels, flatfishes) or habitat preferences (i.e. benthic, demersal sps.) (Table 1). Therefore, specific groups of fishes (single species or group of species) were used for further analysis. Abundance of captured fish was evaluated through mean daily catch per group of fish, which was standardised as mean number of individuals per fishing day within sampling period (ind. day ${ }^{-1}$ ). Catchability was estimated as the proportion of days a group of fish was present

Table 1 List of fish groups (common names) and species (scientific names) captured by fish traps during the study period

\begin{tabular}{|c|c|c|c|c|c|c|c|}
\hline \multirow{2}{*}{$\begin{array}{l}\text { Groups of fishes } \\
\text { (com. name) }\end{array}$} & \multicolumn{5}{|c|}{ Abundance $( \pm \mathrm{SE})$} & \multirow{2}{*}{$\begin{array}{l}\text { Species } \\
\text { (sci. name) }\end{array}$} & \multirow[t]{2}{*}{ Habitat } \\
\hline & Vatnefjorden & Frænfjorden & Bolsøya & Måndalen & Eresfjord & & \\
\hline Sea trout & $4.27 \pm 0.69$ & $3.52 \pm 0.34$ & $2.41 \pm 0.45$ & $18.27 \pm 3.03$ & $1.25 \pm 0.20$ & S. trutta & B P N \\
\hline Atlantic salmon & $0.02 \pm 0.02$ & $0.01 \pm 0.01$ & $0 \pm 0$ & $0.19 \pm 0.11$ & $0.02 \pm 0.01$ & S. salar & B P N \\
\hline Farmed salmon & $0.11 \pm 0.06$ & $0.01 \pm 0.01$ & $0 \pm 0$ & $0.28 \pm 0.21$ & $0.26 \pm 0.09$ & S. salar & B P N \\
\hline Saithe & $25.87 \pm 6.37$ & $10.76 \pm 1.69$ & $18.24 \pm 2.49$ & $7.89 \pm 1.77$ & $4.39 \pm 0.76$ & $P$. virens & B D \\
\hline Pollack & $0.83 \pm 0.07$ & $0.45 \pm 0.04$ & $1.89 \pm 0.16$ & $6.28 \pm 0.73$ & $2.68 \pm 0.25$ & P. pollachius & B D \\
\hline Atlantic cod & $0.53 \pm 0.11$ & $2.49 \pm 0.31$ & $1.64 \pm 0.16$ & $0.78 \pm 0.13$ & $0.86 \pm 0.14$ & G. morhua & B D \\
\hline Other Gadids & $0.03 \pm 0.03$ & $0.01 \pm 0.01$ & $0 \pm 0$ & $0.05 \pm 0.03$ & $0.13 \pm 0.13$ & $\begin{array}{l}\text { B. brosme } \\
\text { M. merluccius } \\
\text { M. aeglefinus } \\
\text { T. minutus }\end{array}$ & $\begin{array}{l}\text { B D } \\
\text { B D } \\
\text { B D } \\
\text { B D }\end{array}$ \\
\hline Herring & $1.26 \pm 0.45$ & $1.04 \pm 0.51$ & $0.64 \pm 0.13$ & $2.78 \pm 0.80$ & $1.31 \pm 0.25$ & C. harengus & $\mathrm{P}$ \\
\hline Mackerels & $0.94 \pm 0.23$ & $0.31 \pm 0.09$ & $0.44 \pm 0.09$ & $2.28 \pm 1.47$ & $0.88 \pm 0.25$ & $\begin{array}{l}\text { T.trachurus } \\
\text { S. scombrus }\end{array}$ & $\begin{array}{l}\mathrm{P} \\
\mathrm{P}\end{array}$ \\
\hline Garfish & $0.02 \pm 0.01$ & $0.03 \pm 0.01$ & $0.03 \pm 0.02$ & $0.74 \pm 0.18$ & $0.27 \pm 0.09$ & B. belone & $\mathrm{P}$ \\
\hline Lumpsucker & $0 \pm 0$ & $0.04 \pm 0.02$ & $0.01 \pm 0.01$ & $0.08 \pm 0.05$ & $0.02 \pm 0.01$ & C..lumpus & B P \\
\hline Flatfishes & $0.01 \pm 0.01$ & $2.55 \pm 0.28$ & $0.04 \pm 0.02$ & $0.27 \pm 0.08$ & $0.08 \pm 0.03$ & $\begin{array}{l}P . \text { platessa } \\
\text { S. maximus }\end{array}$ & $\begin{array}{l}\mathrm{B} \\
\mathrm{B}\end{array}$ \\
\hline $\begin{array}{l}\text { Other benthic } \\
\text { fishes }\end{array}$ & $0 \pm 0$ & $0.12 \pm 0.03$ & $0.01 \pm 0.01$ & $0 \pm 0$ & $0 \pm 0$ & $\begin{array}{l}\text { A. cataphractus } \\
\text { E. gurnardus } \\
\text { L. piscatorius } \\
\text { Scorpaena } \text { sps. }\end{array}$ & $\begin{array}{l}\mathrm{B} \\
\mathrm{B} \\
\mathrm{B} \\
\mathrm{B}\end{array}$ \\
\hline $\begin{array}{l}\text { Small demersal } \\
\text { fishes }\end{array}$ & $0.03 \pm 0.02$ & $2.47 \pm 0.44$ & $0.01 \pm 0.01$ & $0.46 \pm 0.46$ & $0.03 \pm 0.02$ & $\begin{array}{l}\text { Labrus sps. } \\
\text { C. exoletu, } \\
\text { C. rupestris } \\
\text { S. melops } \\
\text { S. spinachia } \\
\text { S. typhle }\end{array}$ & $\begin{array}{l}\mathrm{D} \\
\mathrm{D} \\
\mathrm{D} \\
\mathrm{D} \\
\mathrm{D} \\
\mathrm{D}\end{array}$ \\
\hline Catadromous eels & $0.02 \pm 0.02$ & $0.03 \pm 0.01$ & $0 \pm 0$ & $0 \pm 0$ & $0 \pm 0$ & A. anguila & B P \\
\hline
\end{tabular}

Abundance of groups of fishes (fish per day \pm standard error) and habitat preference of fish species $(B$ benthic, $P$ pelagic, $N$ neritic, $D$ demersal) at each sampling location are also shown 
in the catch from total fishing days throughout the study period. Occurrence was estimated as the presence of a certain group of fish within sampling season (months) throughout the study period (as a percentage). Fish diversity or richness was estimated as the number of different group of fish present within captures at each sampling locality and year. In addition, sea water temperature $\left( \pm 0.1^{\circ} \mathrm{C}\right)$ and salinity (p.s.u.) data were daily recorded at $3 \mathrm{~m}$ depth by data loggers and/or provided by nearby salmon fish farms within each location. Nonparametric multivariate techniques were used to assess the spatio-temporal variations on daily catch of groups of fishes throughout the study period. Fourth Roots transformation was used to homogenize the variance among samples. Triangular similarity matrices were calculated using the Bray-Curtis similarity coefficient. Similarities among sampling locations according to daily catch of groups of fishes were calculated using the SIMPER (similarity percentages) procedure. Moreover, a principal component analysis (PCA) was applied as a cluster method to assess differences among sampling locations regarding daily catch of most abundant fish species throughout the study period. Generalized linear models (GLM) were applied to assess spatio-temporal variations in daily catch of the most abundant fish species (dependent variable) among sampling locations, months and years (fixed factors) $\left(5^{*} 4 * 3\right)$. Pearson correlations were used to assess the relationship among environmental variables (sea water temperature and salinity) and daily catch of the most abundant fish species throughout the study period. Analyses were performed using the statistical packages PRIMER 6 and IBMSPSS Statistics 2.0.

\section{Results}

Twenty-three fish species were captured by traps during the sampling period. They were clustered into 15 groups of fishes (single species or groups, see Table 1): sea trout (S. trutta), wild Atlantic salmon (S. salar), farmed/escaped salmon (S. salar), saithe (Pollachius virens), pollack (Pollachius pollachius), Atlantic cod (Gadus morhua), other gadids (Brosme brosme, Merluccius merluccius, Melanogrammus aeglefinus, Trisopterus minutus), herring (Clupea harengus), mackerels (Trachurus trachurus and Scomber scombrus), garfish (Belone belone), lumpsucker (Cyclopterus lumpus), flatfishes (Pleuronectes platessa and Scophthalmus maximus), other benthic fishes (Agonus cataphractus, Eutrigla gurnardus, Lophius piscatorius, Scorpaena sps.), small demersal fishes (Labrus sps., Centrolabrus exoletus, Ctenolabrus rupestris, Symphodus melops, Spinachia spinachia, Sygnathus typhle) and catadromous eels (Anguila anguila). In general, saithe was the most common species captured by traps during the whole sampling period $\left(14.4 \pm 1.6\right.$ ind day $\left.^{-1}\right)$, followed by sea trout $\left(4.8 \pm 0.5\right.$ ind. day $\left.{ }^{-1}\right)$ and pollack $\left(2.1 \pm 0.2\right.$ ind. day $\left.{ }^{-1}\right)$ (Fig. 2). The greatest catchabilities $(\% \mathrm{C})$ were recorded on saithe $(77.3 \% \mathrm{C})$ and sea trout $(69.1 \% \mathrm{C})$, while the highest percentages of occurrence $(\% \mathrm{O})$ were recorded on saithe, sea trout, cod and herring (all of them $100 \% \mathrm{O}$ ) (Fig. 2). In addition, farmed salmon presented greater presence $\left(0.2 \pm 0.1\right.$ ind. day $\left.{ }^{-1}\right)$, occurrence $(40 \% \mathrm{O})$ and catchability $(4.9 \% \mathrm{C})$ than wild salmon $\left(0.05 \pm 0.01\right.$ ind. day $\left.{ }^{-1} ; 26.7 \% \mathrm{O} ; 1.8 \% \mathrm{C}\right)$ (Fig. 3). Principal component analysis (PCA) showed that two principal components explained the $45.3 \%$ of total variation on daily catch among samples (Fig. 3). According to PCA, saithe was the greatest contributing species (coefficient: 0.958), followed by pollack (coefficient: -0.209 ) and sea trout (coefficient: 0.149), for the first principal component (PC1) which explained $26.1 \%$ of total variation (Fig. 3). Moreover, sea trout (coefficient: -0.876 ) was the most contributing species, followed by pollack (coefficient: -0.383) and cod (coefficient: -0.180 ), for the second principal component (PC2) which explained $19.2 \%$ of total variation (Fig. 3). Regarding sampling locations, saithe was the most abundant fish in Vatnefjorden $\left(25.87 \pm 6.37\right.$ ind. day $\left.{ }^{-1}\right)$, Frænfjorden $(10.76 \pm 1.69$ ind. day $\left.^{-1}\right)$, Bolsøya $\left(18.24 \pm 2.49\right.$ ind. day $\left.{ }^{-1}\right)$ and Eresfjord $\left(4.39 \pm 0.76\right.$ ind. day $\left.{ }^{-1}\right)$, while sea trout was the most abundant in Måndalen (18.27 \pm 3.03 ind. day $\left.{ }^{-1}\right)$ throughout the whole sampling period (Table 1).

Fish diversity or richness varied among sampling locations, season and years (Table 2).

In 2011, the highest richness (numbers of fish groups) were recorded in Fraenfjorden (7 fish groups in May, June and July) and Bolsoya (7 fish groups in August). In 2012, the highest richness were recorded in Fraenfjorden in all seasons (8 fish groups in May and July, 7 fish groups in June and August). In 2013, the highest richness were recorded in Mandalen and Eresfjord (9-11 fish groups in July and August), but also in Vatnefjorden and Fraenfjorden (fish groups in June) (Table 2). Mean daily catch composition within each location also varied throughout the study period (Table 3). According to SIMPER analysis, Bolsøya presented the greatest similarity $(51.8 \%$ ) and Eresfjord showed the least $(34.4 \%)$ (Table 3). Saithe was the most 


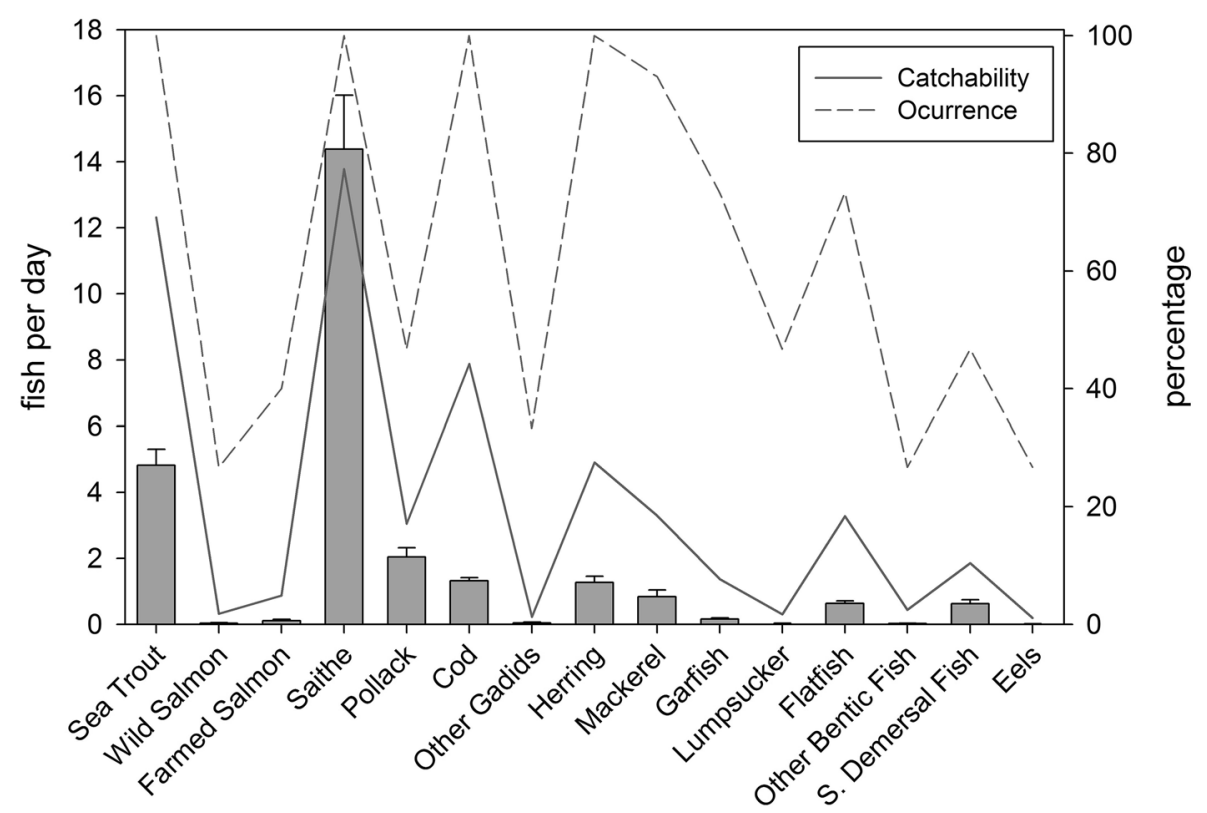

Fig. 2 Mean daily catch per species (mean number of fish per day with standard errors; in dark bars) and percentages of catchability (solid line) and occurrence (dashed line) of captured fish species and groups during the study period

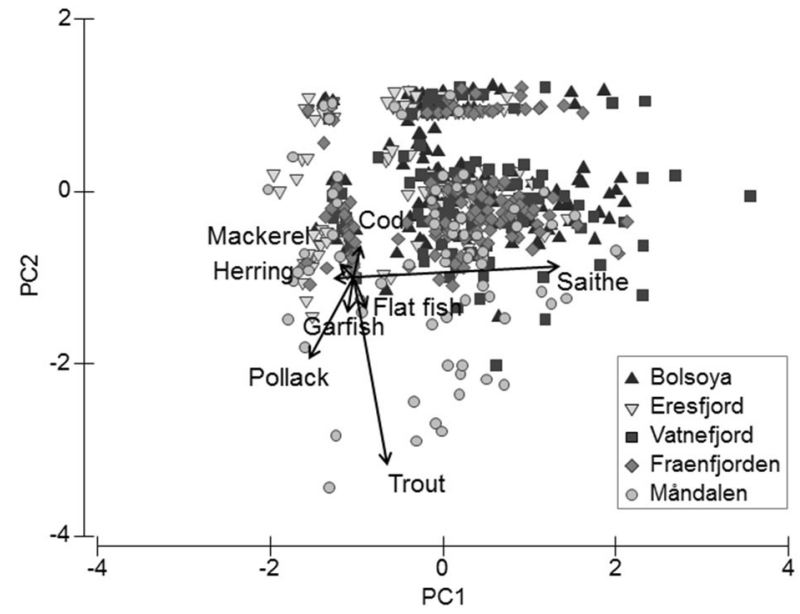

Fig. 3 Scatter-plot from principal components analysis (PCA) for mean daily catch of fish species and groups captured by traps at different locations throughout the study period. Principal component 1 (PC1) explained $26.1 \%$ of total variance. Principal component 2 (PC2) explained $19.2 \%$ of the total variance

contributing fish to similarities on mean daily catch within Bolsøya (54.9\%), Eresfjord (52.1\%), Vatnefjorden $(48.9 \%)$ and Frænfjorden $(34.3 \%)$, while sea trout was the most contributing fish to similarities within Måndalen (44.1\%) (Table 3). In fact, both fish species presented the greatest contributions in all locations, followed by cod and herring (Table 3). Therefore, significant spatial and temporal variations were found on mean daily catch of the most abundant fish species (Fig. 4; Table 4). For instance, captures of sea trout were greater in Måndalen and especially during June, while captures of saithe were greater in Bolsøya and Vatnefjorden, with the greatest values during July (Fig. 4; Table 4). For pollack, mean daily catches were greater in the inner part of the study area (Måndalen and Eresfjord) from June to August, while captures of cod were greater in northern areas (Bolsøya and Frænfjorden), with no differences among sampling seasons (Fig. 4; Table 4). Captures of herring was greater in Måndalen, but also in Bolsøya and Eresfjord, while no 
Table 2 Fish diversity or richness of captured fish (number of groups of fishes) recorded at different sampling locations and seasons (M: May, Jn: June, Jl: July, A: August) during the study period

\begin{tabular}{|c|c|c|c|c|c|c|c|c|c|c|c|c|}
\hline & \multicolumn{4}{|c|}{2011} & \multicolumn{4}{|c|}{2012} & \multicolumn{4}{|c|}{2013} \\
\hline & M & Jn & $\mathrm{J} 1$ & A & M & Jn & $\mathrm{Jl}$ & A & M & Jn & $\mathrm{J} 1$ & A \\
\hline Vatnefjorden & 3 & 4 & 4 & 5 & 4 & 5 & 6 & 4 & 2 & 9 & 7 & 6 \\
\hline Frænfjorden & 7 & 7 & 7 & 3 & 8 & 7 & 8 & 7 & 5 & 9 & 6 & 7 \\
\hline Bolsøya & 5 & 6 & 4 & 7 & 5 & 5 & 4 & 5 & 5 & 5 & 5 & 6 \\
\hline Måndalen & 4 & 4 & 6 & 4 & 6 & 4 & 5 & 5 & 4 & 8 & 9 & 11 \\
\hline Eresfjord & 3 & 4 & 6 & 5 & 6 & 4 & 4 & 5 & 4 & 6 & 9 & 10 \\
\hline
\end{tabular}

Table 3 Percentage similarities within sampling locations regarding daily captures of groups of fishes (mean daily catch), and their contribution to the overall similarities, resulting from SIMPER analysis

\begin{tabular}{lccccc}
\hline & Vatnefjorden & Frænfjorden & Bolsøya & Måndalen & Eresfjord \\
\hline Similarities & 46.2 & 46.8 & 51.8 & 41.8 & 34.4 \\
Contributions & & & & & \\
Saithe & $48.9^{*}$ & $34.3^{*}$ & $54.9^{*}$ & $26.8^{*}$ & $52.1^{*}$ \\
Sea trout & $41.5^{*}$ & $29.3^{*}$ & $19.6^{*}$ & $44.1^{*}$ & $16.4^{*}$ \\
Cod & 2.8 & $12.3^{*}$ & $18.5^{*}$ & $9.7^{*}$ & $12.9^{*}$ \\
Herring & 4.0 & 0.6 & 4.1 & $9.5^{*}$ & $5.8^{*}$ \\
Pollack & 0.7 & 0.2 & 1.1 & 1.4 & $5.9^{*}$ \\
Mackerel & 1.9 & 1.0 & 1.7 & 0.7 & 2.5 \\
Flatfish & $<0.1$ & $16.1^{*}$ & $<0.1$ & 2.1 & 0.3 \\
Garfish & $<0.1$ & $<0.1$ & $<0.1$ & & 1.2 \\
\hline
\end{tabular}

* Main contributors up to $90 \%$ within each location

differences between locations were found for mean daily catch of mackerel, captured more abundantly during August compared to the other sampling seasons (Fig. 4; Table 4).

Pearson correlations indicated that sea water temperature and salinity were negatively correlated (correlation $C=-0.469, p<0.01$ ). On the other hand, these parameters were significantly correlated with some abundant fish species according to mean daily catch throughout the whole study period (Table 5). Thus, sea water temperature was correlated significantly and positively with captures of saithe $(C=0.126, p<0.01)$ and mackerel $(C=0.157, p<0.01)$, and significantly and negatively correlated with captures of sea trout $(C=-0.237, p<0.01)$ (Table 5). Salinity was correlated significantly and negatively with captures of pollack $(C=-0.165, p<0.01)$ and mackerel $(C=-0.125, p<0.01)$ (Table 5). Furthermore, mean daily catches of sea trout were correlated significantly and positively with captures of saithe $(C=0.089, p<0.05)$ and pollack $(C=0.133, p<0.01)$, and significantly and negatively with $\operatorname{cod}(C=-0.102, p<0.05)$ and mackerel $(C=-0.110, p<0.05)$ (Table 5). Captures of saithe and pollack were significantly and negatively related between them $(C=-0.155, p<0.01)$, while mean daily catches of mackerel were significantly and positively correlated with captures of herring $(C=0.153, p<0.01)$ and pollack $(C=0.097, p<0.05)$ (Table 5).

\section{Discussion}

In this region, fish traps are common and effective devices to capture salmonids, both sea trout and wild salmon, since they share some seasonal and migrational routes along Norwegian coastal marine waters during spring and summer (e.g. Holm et al. 2000; Jonsson and Jonsson 2006). However, other fish species are also captured, providing additional data on the dynamics of coastal fish assemblages in the Norwegian fjords. The 

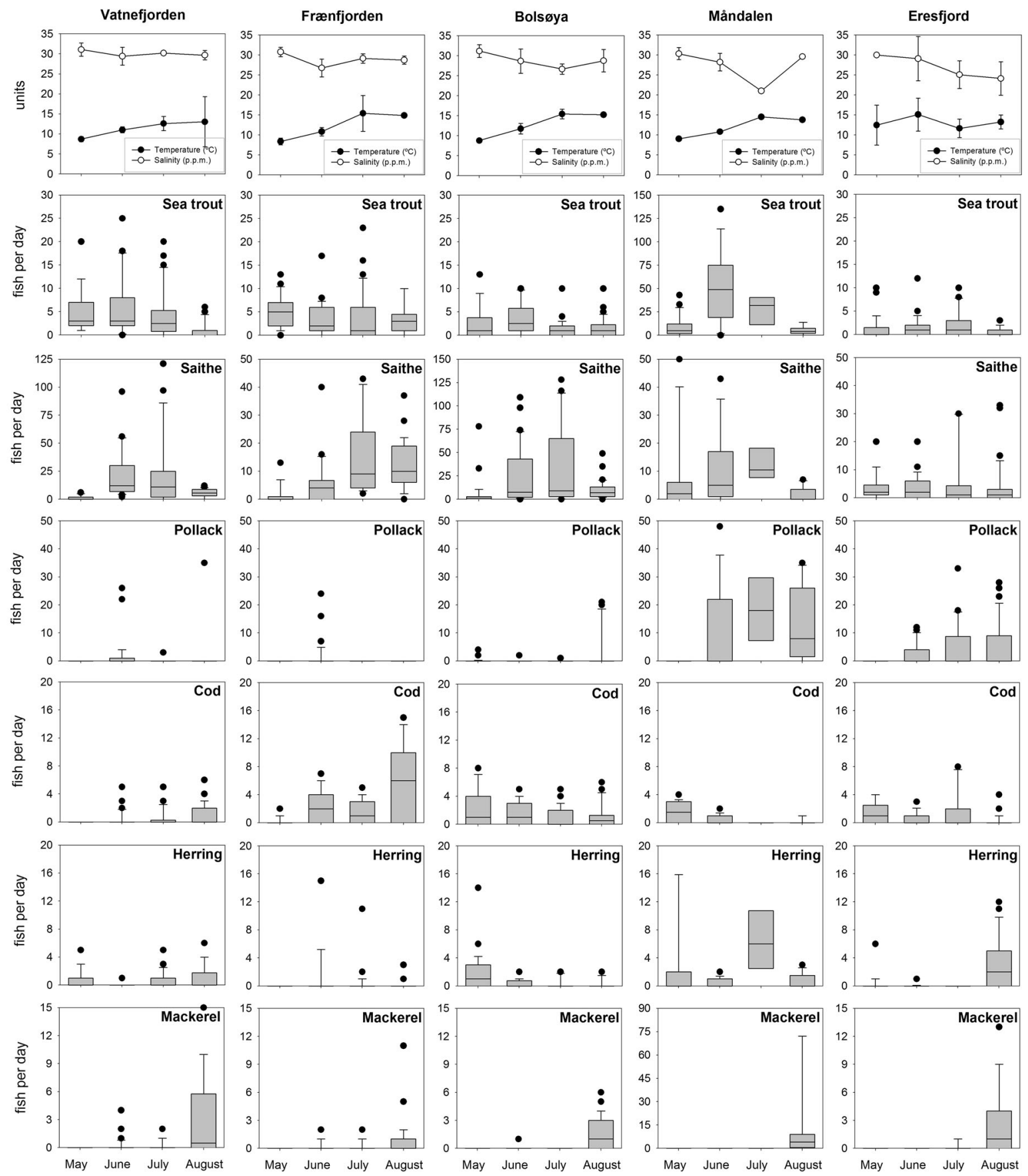

Fig. 4 Monthly variations of mean sea water temperature $( \pm \mathrm{SE})$ and salinity $( \pm \mathrm{SE})$ (upper lines), and mean daily catch of the most abundant fish (in box-plots) recorded at different locations of Romsdalsfjord region during the study period

presence, abundance and catch variability of fish species recorded in this work agrees with previous findings in other coastal regions of Norway, where gadids dominated catches of demersal fishes (e.g. Salvanes and Nordeide 1993; Lekve et al. 1999, 2002; Olsen et al. 2010). Saithe, cod and pollack are the most common gadids inhabiting Norwegian kelp forests and rocky coastal waters, which are important foraging and refuge habitats for juveniles and adult fish (e.g. Gjøsæter and Danielssen 1990; Rangeley and Kramer 1995a, b; Fromentin et al. 1997), being thus more susceptible to be captured by traps. They feed on crustaceans and other fishes, and previous studies have demonstrated that they feed on their own (cannibalism) and each other's juveniles (e.g. Salvanes and Nordeide 1993; Salvanes 1995; Bromley et al. 1997). Saithe and pollack 
Table 4 Results from the generalized linear model (GLM) of mean daily catches of the most abundant fish species (dependent variables) regarding sampling locations (Loc), months (Mon) and years (Year)

\begin{tabular}{|c|c|c|c|c|c|c|c|c|c|c|}
\hline & \multicolumn{5}{|c|}{ Sea trout } & \multicolumn{5}{|c|}{ Saithe } \\
\hline & $d f$ & MS & $F$ & $p$ value & Sig. & $d f$ & MS & $F$ & $p$ value & Sig. \\
\hline Location (Loc) & 4 & 8.266 & 2.591 & 0.116 & & 4 & 4.803 & 0.929 & 0.929 & \\
\hline Month (Mon) & 3 & 3.294 & 2.264 & 0.177 & & 3 & 11.361 & 7.651 & 0.017 & $*$ \\
\hline Year & 2 & 0.164 & 0.041 & 0.960 & & 2 & 8.667 & 1.626 & 0.257 & \\
\hline Loc $\times$ mon & 12 & 1.408 & 1.993 & 0.072 & & 12 & 2.063 & 1.465 & 0.208 & \\
\hline Loc $\times$ year & 8 & 3.487 & 4.715 & 0.002 & $* *$ & 8 & 5.654 & 3.904 & 0.005 & $* *$ \\
\hline Mon $\times$ year & 6 & 1.677 & 2.263 & 0.073 & & 6 & 1.714 & 1.183 & 0.350 & \\
\hline Loc $\times$ mon $\times$ year & 22 & 0.761 & 2.444 & 0.001 & $* *$ & 22 & 1.552 & 5.021 & 0.001 & $* *$ \\
\hline \multirow[t]{3}{*}{ Residuals } & 484 & 0.311 & & & & 484 & 0.309 & & & \\
\hline & \multicolumn{5}{|c|}{ Pollack } & \multicolumn{5}{|c|}{ Cod } \\
\hline & $d f$ & MS & $F$ & $p$ value & Sig. & $d f$ & MS & $F$ & $p$ value & Sig. \\
\hline Location (Loc) & 4 & 4.384 & 0.801 & 0.558 & & 4 & 4.934 & 1.998 & 0.188 & \\
\hline Month (Mon) & 3 & 3.626 & 2.050 & 0.211 & & 3 & 0.280 & 0.504 & 0.693 & \\
\hline Year & 2 & 11.093 & 1.816 & 0.221 & & 2 & 3.548 & 1.682 & 0.272 & \\
\hline Loc $\times$ mon & 12 & 1.635 & 1.224 & 0.327 & & 12 & 1.830 & 1.858 & 0.097 & \\
\hline Loc $\times$ year & 8 & 6.041 & 4.192 & 0.004 & $* *$ & 8 & 2.712 & 2.585 & 0.036 & $*$ \\
\hline Mon $\times$ year & 6 & 2.119 & 1.465 & 0.236 & & 6 & 0.643 & 0.611 & 0.719 & \\
\hline Loc $\times$ Mon $\times$ year & 22 & 1.508 & 19.085 & 0.001 & $* *$ & 22 & 1.090 & 5.001 & 0.001 & $* *$ \\
\hline \multirow[t]{3}{*}{ Residuals } & 484 & 0.079 & & & & 484 & 0.218 & & & \\
\hline & \multicolumn{5}{|c|}{ Herring } & \multicolumn{5}{|c|}{ Mackerel } \\
\hline & $d f$ & MS & $F$ & $p$ value & Sig. & $d f$ & MS & $F$ & $p$ value & Sig. \\
\hline Location (Loc) & 4 & 1.290 & 1.001 & 0.460 & & 4 & 0.221 & 0.510 & 0.731 & \\
\hline Month (Mon) & 3 & 1.498 & 2.667 & 0.133 & & 3 & 12.881 & 33.087 & 0.001 & $* *$ \\
\hline Year & 2 & 0.541 & 0.403 & 0.684 & & 2 & 0.724 & 0.372 & 0.783 & \\
\hline Loc $\times$ mon & 12 & 1.915 & 3.467 & 0.004 & $* *$ & 12 & 0.460 & 0.475 & 0.909 & \\
\hline Loc $\times$ year & 8 & 1.402 & 2.420 & 0.047 & $*$ & 8 & 0.483 & 0.465 & 0.868 & \\
\hline Mon $\times$ year & 6 & 0.633 & 1.090 & 0.398 & & 6 & 0.466 & 0.447 & 0.840 & \\
\hline Loc $\times$ mon $\times$ year & 22 & 0.597 & 2.610 & 0.001 & $* *$ & 22 & 1.085 & 8.903 & 0.001 & $* *$ \\
\hline Residuals & 484 & 0.229 & & & & 484 & 0.122 & & & \\
\hline
\end{tabular}

$* p$ value $<0.05, * * p$ value $<0.01$

Table 5 Pearson correlation matrix between environmental variables and mean daily catches of the most abundant fish species throughout the study period

\begin{tabular}{|c|c|c|c|c|c|c|c|c|}
\hline & Temperature & Salinity & Sea trout & Saithe & Pollack & Cod & Herring & Mackerels \\
\hline Temperature & 1 & $-0.469 * *$ & $-0.237 * *$ & $0.126 * *$ & 0.015 & 0.075 & -0.079 & $0.157 * *$ \\
\hline Salinity & & 1 & 0.056 & -0.012 & $-0.165^{* *}$ & -0.030 & -0.074 & $-0.125 * *$ \\
\hline Sea trout & & & 1 & $0.089 *$ & $0.133 * *$ & $-0.102 *$ & 0.010 & $-0.110 * *$ \\
\hline Saithe & & & & 1 & $-0.155^{* *}$ & 0.034 & -0.076 & -0.041 \\
\hline Pollack & & & & & 1 & 0.003 & 0.013 & 0.097* \\
\hline Cod & & & & & & 1 & 0.007 & -0.043 \\
\hline Herring & & & & & & & 1 & $0.153 * *$ \\
\hline Mackerel & & & & & & & & 1 \\
\hline
\end{tabular}

$* p$ value $<0.05, * * p$ value $<0.01$ 
were positively correlated in this study, probably due to their use of similar feeding areas (Sarno et al. 1994). However, no correlations were detected between both species and the presence of cod. Cod presents a wider diet range, feeding on many prey items varying along the Norwegian coast (Svåsand et al. 2000). However, the negative significant correlation between cod and sea trout found in this study might reflect cod dietary preference on migrating post-smolts salmonids in the Romsdalsfjord area (Hedger et al. 2011).

Herring (C. harengus) and mackerels (T. trachurus, S. scombrus) were also frequently caught by traps throughout the study. The presence and distributions of these planktivorous species of commercial interest are usually correlated, but both populations display spatial and temporal differences (Langøy et al. 2012; Utne et al. 2012). Although these species frequently use the same feeding and spawning areas, mackerels seemed to prefer warmer water than herring (Utne et al. 2012), and therefore, occurred near surface (0-5 m) more frequently during summer. Some flatfishes of commercial interest were also captured during this study, but to a less extent than gadids or small pelagic fishes. Flatfishes such as plaice ( $P$. platessa) and turbot (S. maximus) are generally abundant far inside fjords, living on sandy, rocky or mixed bottoms of shallow brackish waters (Albert et al. 1998). Although these traps were not specifically designed for this kind of bentho-demersal fish (He and Inoue 2010) some individuals might be trapped during spawning or feeding on shallow coastal waters. On their turn, small demersal fishes such as wrasses (e.g. L. bergylta, L. bimaculatus, C. exoletus, C. rupestris, $S$. melops) were captured in very less numbers probably due to the large mesh size of the traps in this study. They are commonly found in shallow rocky bottoms along the coast of Norwegian fjords (Salvanes and Nordeide 1993), and expected to be found within trap captures (Darwall et al. 1992; Bjordal 1993; Barlaup et al. 2013). Other migratory species, such as the pelagic garfish (B. belone) and the benthopelagic lumpsucker (C. lumpus), were also captured in this study, but they presented less abundance and a great spatial and temporal heterogeneity. These species were not targeted in the study area but can be accidentally caught as bycatch in outer fisheries (e.g. Evans et al. 1994; van Marlen et al. 2014). The catadromous eel (A. anguilla) was rarely captured, probably due to the large mesh size (Poole 1990; Chisnall and West 1996) or a seasonal effect, since seaward migrations mainly occur during autumn (Haraldstad et al. 1985; Vøllestad 1986).

The present study has provided additional data about species composition and spatio-temporal variations of coastal fish communities in Romsdalsfjord region, and complement results from previous works along Norwegian coast (e.g. Nash 1988; Salvanes and Nordeide 1993; Fromentin et al. 1997; Lekve et al. 1999, 2002). Coastal fish population dynamics are influenced by species-specific biological characteristics and interspecific ecological processes, such as differences in spawning and feeding migrations, competence and use of resources, environmental fluctuations (e.g. sea water temperature and salinity), and prey-predator relationship, among others. However, fishing also influences fish assemblages, mostly due to increased direct and indirect mortality of targeted fish, and in most cases also for non-targeted species, that might affect the status of local stocks, fish dynamics and marine ecosystem functioning (Jennings and Kaiser 1998). Other anthropogenic activities, such as salmon aquaculture, might also influence the spatiotemporal distribution of fish (Goodbrand et al. 2013), since many species reported in this study are commonly attracted by farm facilities (Dempster et al. 2009). Further research is needed to increase the existing knowledge on Norwegian coastal fish population dynamics, by sampling with diverse fishing methods, different periods and diverse environmental conditions. Nevertheless, since traps capture a wide range of fish sizes and species of diverse ecological guilds, this fishing method is highly recommended for fish ecology and tagging studies, to better understand fish population dynamics and developing further sustainable management strategies to preserve fish stocks.

Acknowledgments The Norwegian Research Council (Project No. 221404), the Norwegian Institute for Nature Research (Strategic Institute Programme, Project No. 160022/F40), the Institute of Marine Research, the fish farmers in the Romsdalsfjord area, Møre and Romsdal County Community (Marine Environmental and Value Creation Fund), the County Governor of Møre and Romsdal, the Norwegian Food Safety Authority and the NILS Science and Sustainability program (ES07-EEA Grants; ABEL-IM-2014A) funded this project. Arne Kvalvik, Peder Naalsund, Birk Rosvoll Finstad, Reidar Kvam and Alison Harvey are thanked for excellent support during the fieldwork. The experiment described was approved by the local responsible laboratory animal science specialist under the surveillance of the Norwegian Animal Research Authority (NARA) and registered by the Authority (FOTS ID 2014/29314).

Open Access This article is distributed under the terms of the Creative Commons Attribution 4.0 International License (http:// creativecommons.org/licenses/by/4.0/), which permits unrestricted use, distribution, and reproduction in any medium, provided you give appropriate credit to the original author(s) and the source, provide a link to the Creative Commons license, and indicate if changes were made. 


\section{References}

Albert OT, Eliassen JE, Høines Å (1998) Flatfishes of Norwegian coasts and fjords. J Sea Res 40:153-171

Arechavala-Lopez P, Uglem I, Berg M, Bjørn PA, Finstad B (2016) Large-scale use of traps to monitor sea trout (Salmo trutta) smolts and sea lice (Lepeophtheirus salmonis) infestations: efficiency and reliability. Mar Biol Res 12:76-84

Barlaup BT, Gabrielsen SE, Løyland J, Schläppy ML, Wiers T, Vollseta KW, Pulg U (2013) Trap design for catching fish unharmed and the implications for estimates of sea lice (Lepeophtheirus salmonis) on anadromous brown trout (Salmo trutta). Fish Res 139:43-46

Bjordal $\AA$ (1993) Capture techniques for wrasse (Labridae). ICES Council Meeting papers B:22. pp 3

Bromley PJ, Watson T, Hislop JRG (1997) Diel feeding patterns and the development of food webs in pelagic 0-group cod (Gadus morhua L.), haddock (Melanogrammus aeglefinus L.), whiting (Merlangius merlangus L.), saithe (Pollachius virens L.), and Norway pout (Trisopterus esmarkii Nilsson) in the northern North Sea. ICES J Mar Sci 54(5):846-853

Chisnall BL, West DW (1996) Design and trials of a large fine-meshed fyke net for eel capture, and factors affecting size distribution of catches. New Zeal J Mar Fresh Res 30(3):355-364

Chittenden CM, Rikardsen AH, Skilbrei OT, Davidsen JG, Halttunen E, Skarðhamar J, McKinley RS (2011) An effective method for the recapture of escaped farmed salmon. Aquacult Env Int 1:215-224

Darwall WRT, Costello MJ, Donnelly R, Lysaght S (1992) Implications of life-history strategies for a new wrasse fishery. J Fish Biol 41:111-123

Dempster T, Uglem I, Sanchez-Jerez P, Fernandez-Jover D, Bayle-Sempere JT, Nilsen R, Bjørn PA (2009) Coastal salmon farms attract large and persistent aggregations of wild fish: an ecosystem effect. Mar Ecol Prog Ser 385:1-14

Evans SM, Hunter JE, Wahju RI (1994) Composition and fate of the catch and bycatch in the Farne Deep (North Sea) Nephrops fishery. ICES J Mar Sci 51(2):155-168

Fromentin JM, Stenseth NC, Gjøsæter J, Bjørnstad ON, Falck W, Johannessen T (1997) Spatial patterns of the temporal dynamics of three gadoid species along the Norwegian Skagerrak coast. Mar Ecol Prog Ser 155:209-222

Gabriel O, Lange K, Dahm E, Wendt T (2005) Von Brandt's fish catching methods of the world, 4th edn. Fishing News Books and Blackwell Publishing Ltd, Oxford, p 523

Gjøsæter J, Danielssen DS (1990) Recruitment of cod (Gadus morhua), whiting (Merlangius merlangus) and pollack (Pollachius pollachius) in the Risør area on the Norwegian Skagerrak coast 1945 to 1985. Flødevigen rapportserie 1:1990

Goodbrand L, Abrahams MV, Rose GA (2013) Sea cage aquaculture affects distribution of wild fish at large spatial scales. Can J Fish Aqua Sci 70(9):1289-1295

Halttunen E, Rikardsen AH, Davidsen JG, Thorstad EB, Dempson JB (2009) Survival, migration speed and swimming depth of Atlantic salmon kelts during sea entry and fjord migration. Tagging Track Marine Animals Electron Devices 9:35

Haraldstad Ø, Vøllestad LA, Jonsson B (1985) Descent of European silver eels, Anguilla anguilla L., in a Norwegian watercourse. J Fish Biol 26(1):37-41

He P, Inoue Y (2010) Large-scale Fish traps: gear design, fish behavior, and conservation challenges. In: Pingguo He (Eds) Behavior of marine fishes capture processes and conservation challenges. Chapter 7. PP 159-180. Blackwell Publishing Ltd. pp 402

Hedger RD, Uglem I, Thorstad EB, Finstad B, Chittenden CM, Arechavala-Lopez P, Jensen AJ, NIlsen R, Økland F (2011) Behaviour of Atlantic cod, a marine fish predator, during Atlantic salmon post-smolt migration. ICES J Mar Sci 68(10):2152-2162

Holm M, Holst JC, Hansen LP (2000) Spatial and temporal distribution of post-smolts of Atlantic salmon (Salmo salar L.) in the Norwegian Sea and adjacent areas. ICES J Mar Sci 57(4):955-964

Jennings S, Kaiser MJ (1998) The effects of fishing on marine ecosystems. Adv Mar Biol 34:201-352

Jonsson B, Jonsson N (2006) Cultured Atlantic salmon in nature: a review of their ecology and interaction with wild fish. ICES J Mar Sci 63(7):1162-1181

Langøy H, Nøttestad L, Skaret G, Broms C, Fernö A (2012) Overlap in distribution and diets of Atlantic mackerel (Scomber scombrus), Norwegian spring-spawning herring (Clupea harengus) and blue whiting (Micromesistius poutassou) in the Norwegian Sea during late summer. Mar Biol Res 8(5-6):442-460

Lehtonen E, Suuronen P (2004) Mitigation of seal-induced damage in salmon and whitefish trapnet fisheries by modification of the fish bag. ICES J Mar Sci 61(7):1195-1200

Lekve K, Stenseth N, Gjøsaeter J, Fromentin JM, Gray J (1999) Spatio-temporal patterns in diversity of a fish assemblage along the Norwegian Skagerrak coast. Mar Ecol Prog Ser 178:17-27

Lekve K, Boulinier T, Stenseth NC, Gjøsæter J, Fromentin JM, Hines JE, Nichols JD (2002) Spatio-temporal dynamics of species richness in coastal fish communities. Proc R Soc London B Biol Sci 269(1502):1781-1789

Liu Y, Olaf Olaussen J, Skonhoft A (2011) Wild and farmed salmon in Norway-A review. Mar Pol 35(3):413-418

Nash RD (1988) The effects of disturbance and severe seasonal fluctuations in environmental conditions on north temperate shallow-water fish assemblages. Est Coast Shelf Sci 26(2):123-135

Olsen E, Aanes S, Mehl S, Holst JC, Aglen A, Gjøsæter H (2010) Cod, haddock, saithe, herring, and capelin in the Barents Sea and adjacent waters: a review of the biological value of the area. ICES J Mar Sci 67(1):87-101

Poole WR (1990) Summer fyke nets as a method of eel capture in a salmonid fishery. Aquacult Res 21(2):259-262

Rangeley RW, Kramer DL (1995a) Use of rocky intertidal habitats by juvenile pollock Pollachius virens. Mar Ecol Prog Ser 126(1):9-17

Rangeley RW, Kramer DL (1995b) Tidal effects on habitat selection and aggregation by juvenile pollock Pollachius virens in the rocky intertidal zone. Mar Ecol Prog Ser 126(1):19-29 
Salvanes AGV (1995) Pollack (Pollachius pollachius) stock size development and potential influence on cod (Gadus morhua) mariculture in a west Norwegian fjord. Fish Res 24(3):223-242

Salvanes AGV, Nordeide JT (1993) Dominating sublittoral fish species in a west Norwegian fjord and their trophic links to cod (Gadus morhua L.). Sarsia 78(3-4):221-234

Sarno B, Glass CW, Smith GW (1994) Differences in diet and behaviour of sympatric saithe and pollack in a Scottish sea loch. J Fish Biol 45:1-11

Siira A, Suuronen P, Ikonen E, Erkinaro J (2006) Survival of Atlantic salmon captured in and released from a commercial trapnet: potential for selective harvesting of stocked salmon. Fish Res 80(2):280-294

Skaala Ø, Johnsen GH, Lo H, Borgstrøm R, Wennevik V, Hansen MM, Merzf JE, Glover KA, Barlaup BT (2014) A conservation plan for Atlantic salmon (Salmo salar) and anadromous brown trout (Salmo trutta) in a region with intensive industrial use of aquatic habitats, the Hardangerfjord, western Norway. Mar Biol Res 10(3):308-322

Skilbrei OT, Holm M (2011) High marine survival rates of sea-ranched Atlantic salmon smolts (Salmo salar) that had previously matured as male parr. Fish Man Ecol 18(5):384-391

Skilbrei OT, Jørgensen T (2010) Recapture of cultured salmon following a large-scale escape experiment. Aquacult Env Int $1: 107-115$

Solem Ø, Hedger RD, Urke HA, Kristensen T, Økland F, Ulvan EM, Uglem I (2013) Movements and dispersal of farmed Atlantic salmon following a simulated-escape event. Env Biol Fish 96(8):927-939

Svåsand T, Kristiansen TS, Pedersen T, Salvanes AV, Engelsen R, Naevdal G, Nødtvedt M (2000) The enhancement of cod stocks. Fish Fish 1(2):173-205

Utne KR, Huse G, Ottersen G, Holst JC, Zabavnikov V, Jacobsen JA, Óskarssone GJ, Nøttestad L (2012) Horizontal distribution and overlap of planktivorous fish stocks in the Norwegian Sea during summers 1995-2006. Mar Biol Res 8(5-6):420-441

van Marlen B, Wiegerinck JAM, van Os-Koomen E, van Barneveld E (2014) Catch comparison of flatfish pulse trawls and a tickler chain beam trawl. Fish Res 151:57-69

Vøllestad LA (1986) Temperature-dependent activity of brackish water yellow eels, Anguilla anguilla L. Aquacult Res 17(3):201-205 